\title{
6. PRE-INDUSTRIAL AND INDUSTRIAL RACIAL STRATIFICATION IN SOUTH AFRICA
}

by

\author{
ROBERT ROSS
}

Let us begin with an assumption: the most fitting category with which to analyse the patterns of stratification within modern South Africa are Weberian estates. The problem about so doing, however, is to find a suitable definition of what Weber (or anyone else for that matter) meant by "estates". Weber himself emphasised honour and style of life as the main determinants of an estate, a status, situation, while later commentors have stressed that estates are recruited very largely in terms of primordial loyalties. Individuals are born into estates, but "both propertied and propertyless peoples can belong to the same status group, and frequently they do, with very tangible consequences". Thus, the nations, "tribes" and ethnic groups of southern Africa would seem, at first sight, to be estates, aithough the Weberian criterion of "honour" would have to be replaced by others stressing the ways in which conquest situations created designation of people with presumed distinct ancestry and thus ascription. ${ }^{1}$ When such a categorisation is applied to South Africa, it becomes clear that, on the part of the whites, primordial loyalties in terms of language, religion and colour have been consistently used throughout this century to maintain the solidarity of the ruling group. On the other hand, the whole policy of divide and rule, the whole philosophy behind the Bantustan policy, has been the creation of ethnic estates among the African population. This seems very largely to have failed. There are few leaders in modern South Africa who are prepared to trumpet the claims of, for instance, Zulu nationalism, although at times Gatsha Buthelezi may employ the symbolism of the old Zulu kingdom, for instance in the Inkatha movement. Rather those who have accepted leadership "within the system" of apartheid claim that by playing along with it they may hope to make real gains for particular sections of the black population. Nevertheless, the opposition to that policy and to the South African political system throughout this century has been very largely in terms of estate conflict. Even the ANC, for all its strong links with the Communist Party of South Africa, pitched its appeal in terms of the liberal ethas

1. H.H. Gerth and C. Wright Mills, eds., From Max Weber, Essays in Sociology (Londor. 1948), pp. 186-87.

(5) 1982 Martinus Nijhoff Publishers, The Hague. Printed in the Netherlands. 
entailing the elimination of racial differences and the establishment of an estateless (but by no means implicitly nor necessarily classless) society. The other groups in the opposition, most notably the PAC and the Black Consciousness movement of recent years, have positively affirmed the position of blacks as an estate, as an important referential unit, as the force that will bring about the just society. ${ }^{2}$ In other words, South Africa is existentially experienced in terms of racial differences. Those who claim they are South Africans, and nothing else - there are few who describe themselves as South African proletarians or peasants, or bourgeois - do so out of protest against the existing society, since all are aware of where they stand within the institutionalised pattern of racial stratification. For many, of course, there is in fact no choice, and they have been driven to it by the workings of the society.

This may seem to be the tritest of platitudes. What is the point of announcing, at great length and in Germanic jargon, that South Africa is divided between racial groups, and that it is so perceived? Perhaps the relevance of the platitude may be made clearer by considering the conclusion of Immanuel Wallerstein's overview of the applicability of the concept of estates to ethnic conflicts in postindependence Black Africa: Arguing that ethnic conflict tends to derive from the differential access of the various groups - Igbo and Hausa, Kikuyu and Luo, Bemba and Lozi - to particular sectors of the modern economy, he claims his main point to be that "status groups are blurred collective representation of classes. The blurred (and hence incorrect) lines serve the interest of many different elements in most social situations. As social conflict becomes more acute, status group lines approach class line asymptotically, at which point we may see the phenomenon of 'class consciousness'. But the asymptote is never reached.",3

In South Africa, the asymptote is close, so close indeed that it is possible to analyse modern South Africa exclusively in terms of class conflict without doing inordinate injustice to reality. Indeed, it is probable that far less confusion is caused in this way than by concentration on the ideologies of racial differentiation, except insofar as these are seen as deriving from the position of the ideologue within the political economy of South Africa, especially as it has recently been demonstrated conclusively that the very high rate of profit that capital has been able to extract from South Africa derives from the level of exploitation of the labour force. It is this exploitation which is the key fact in modern South African history, and it is this exploitation which makes South Africa such a flashpoint in the modem world. But this exploitation is possible only because of the pressure which can be placed on that major section of the work-force that is black by the exercise of legally enforced racial discrimination, in terms of wage differentials, the job colour bar, access to education, rights of residence and so on. There has

2. Gail M. Gerhart, Black Power in South Africa: the Evolution of an Ideology (Los Angeles and Berkeley, 1978).

3. I. Wallerstein, "Social Conflict in Post-Independence Black Africa: the Concepts of Race and Status Group Reconsidered", in The Capitalist World Economy (Cambridge, 1979), p. 166. 
been a tendency in the recent literature to take the division between the races as given. That is perhaps justified in terms of a polemic with those who held that discrimination retarded the growth of the South African economy. However, for a rounded view of the development of Southern African society ${ }^{4}$ over the last hundred years or so, it is necessary to return to the question that has been begged: how did that racial stratification come into existence and why have the cleavages in South African society remained, at least cognitively, in terms of race, or, as between Afrikaners and other whites, in terms of ethnicity? It is to this problem that this chapter will address itself.

Even if this problem has received little direct attention in the historiography of South Africa, tangentially the major debates within that historiography bear upon it. There were of course those - the founders of South African history, Theal and Cory, and most of the nationalist Afrikaner school in particular for whom the problem did not exist, since they could not imagine a South Africa without clearly defined and hierarchically ordered racial groupings. Rather it was with the emergence of historians who were far more critical towards the society in which they themselves lived - the classic example is W.M. "Pinky" Macmillan" - that the elements of a coherent theory begin to emerge. Both as a consequence of their reading of the historical record and as a reaction to the political struggle they were engaged in in the 1920s and 1930s, they put the blame, and blame it was in their eyes, squarely at the door of the colonists, largely though not exclusively Afrikaner, of the pre-industrial period. Even though they were writing in the heyday of South African industrialisation, when that country profited as did few others from the general world depression, they did not see the social changes of the world around them as influencing the attitudes they deplored. Rather they were a hangover from a time that was now passed, the dead weight of history on modern South Africa. It is typical that, when I.D. MacCrone wrote his influential study in 1937, he was prepared to jump the gap between around 1800 , when his historical work ended, and the 1930s, when he did his psychological testing, with barely a comment. ${ }^{6}$ That century and a third might simply not have existed for him. The white South African character had been formed in the uncertainties and the loneliness of the struggle against the San and the Xhosa, and had not yet been changed.

Implicit in this approach to the South African past was an acceptance of industrial capitalism as a justified and even desirable organisation of society. Even for MacMillan, what was needed in South Africa was "good laws and good government", not a change in the structure of society. ${ }^{7}$ In the last few years, however,

4. By Southern (as opposed to southern) Africa, I mean not so much the geographical region as the society that emanated from the foundation of the Cape Colony in Cape Town, whether or not it eventually became part of the state of South Africa.

5. His nickname referred not only to the colour of his hair, but also to that of his opinions.

6. I.D. MacCrone, Race Attitudes in South Africa: Historical, Experimental and Psycholog. ical Studies (Oxford, 1937).

7. W.M. MacMillan, My South African Years, an Autobiography (Cape Town, 1975), p. 214. 
increasing numbers of historians have challenged the optimistic premises of such reasoning. Together with a desire not so much for new laws as for a new society, a radical reconstruction of South Africa in which the capitalist organisation of production is abolished, they have consistently argued that the capitalists of South Africa have benefited throughout the course of this century from the racial division of labour within the country, and have indeed done much to establish it. The kernel of their argument, ${ }^{8}$ to simplify and skim shamelessly over both the sophistications and the debates among them, is that not only mining but also secondary industry and agriculture have been able to maintain high rates of profit as a result of the low wages they have been able to pay to workers whose bargaining position had been fatally weakened by discriminatory legislation. Moreover, the relative strength of the employer against his employees derived, so it is argued, from the fact that the majority of the labour force had maintained its roots in the rural economy. Thus the employer had no need to pay the reproduction costs of the next generation of labourers. Since the profitability of gold-mining was always particularly sensitive to the cost of labour and since gold-mining has always been far and away the leading sector of the capitalist economy of South Africa, the incomplete absorption of Africans into the capitalist mode of production has kept wages down, below "subsistence" levels, to the great benefit of the economy. Segregationist measures, which were intended to maintain the rural side of the African economy and the articulation of pre-colonial and capitalist modes of production, thus worked to the advantage of capital. It is no chance that the clearest arguments in favour of segregation derived from thinkers who had close connections with the highest levels of capitalism, nor that the introduction of the clear ideals of apartheit among Afrikaners came together with the drive to build up Afrikaner entrepreneurship, from Broederbond circles. ${ }^{10}$

A further strength of this approach is that it provides a much clearer appreciation of the position of those whites who were themselves the employees of capitalist undertakings. This has required a certain redefinition of the concept of class, mainly following the ideas propounded by Poulantzas, but by so doing it has been possible to show that an increasing majority of those whites have been in supervisory positions within industry, in clerical jobs or in the skilled occupation, where their interests have been closely allied with those of the employers. Certainly, the capitalists have felt the need for such cadres, so that, since 1924, there has never been serious conflict between the groups (until 1979,

8. It would be tedious to list a complete bibliography of this school. Their work can be found above all in the journals Economy and Society, Joumal of Southern African Studies and Review of Political Economy.

9. Martin Legassick, "Race, Industrialisation and Social Change in South Africa; the Case of R.F.A. Hoernle", African Affairs 75 (1976).

10. Dan O'Meara, "Afrikaner Broederbond 1927-1948: Class Vanguard of Afrikaner Nationalism", Collected Seminar Papers of the Institute of Commonwealth Studies, London, The Societies of Souther Africa in the Nineteenth and Twentieth Centuries (hereafter SSA) 7 (1977). 
perhaps). Rather both knew well that there were limits that must not be overstepped. It was the knowledge among the white employees that their economic needs would be taken care of that made them so susceptible to extra-economic inducements to political mobilisation, such as the folkloristic aspects of Afrikaner nationalism in the ox-waggon trek to commemorate the centenary of the Great Trek, but also to the primarily emotional struggle for the republic. ${ }^{11}$ But of course they knew that their privileged position as against the blacks would be maintained.

However, there a variety of problems, at least in the literature as it has so far developed, that pertain to the problem of racial stratification and that the neoMarxists ${ }^{12}$ have rather failed to tackle. An argument that capital accumulation in South Africa has been served by the fact that certain groups in the society (the whites) did have access to state power while others (the blacks) did not, is not an argument about the origins of that allocation of power. The most intelligent position is that taken by Stanley Greenberg, who is concerned to investigate the ways in which the capitalist development of South Africa was also be benefit from and to exploit a pre-existing pattern of ethnic stratification. ${ }^{13}$ On the other hand, the general lack of a cogent Marxist theory on the origins of racist stratification in South Africa can be demonstrated from a passage in the recent article by Belinda Bozzoli in which she argues:

It is not difficult to explain how the state in South Africa came to assume its exclusive and racist form in the period of imperial hegemony. Many states under imperialism took similar forms; indeed it is a frequent characteristic of imperial states that they succeed in confining their sphere of legitimacy - though of course not their sphere of repression - to the dominant mode of production. The "colonial" state preserves the hegemony of imperial capital as a whole through an efficient repressive apparatus and limited, centralised and usually nonincorporationist ideological state apparatuses. Imperial hegemony as a resuit takes on a particular (often hierarchical) ideological and structural form.

That is no doubt so, but from the point of view of imperial capital between the 1890 s and the 1920s (her "period of imperial hegemony"), the problem was that too many people had been incorporated into the political process. In the mine strike of 1914 , the mineworkers were able to hold a gun - literally - at the heads of the political representatives of imperial capital, Louis Botha and Jan Smuts. ${ }^{14}$

11. T. Dunbar Moodie, "The Rise of Afrikanerdom as an Immanent Critique of Marxist Theory of Social Class", in Working Papers in Southern African Studies, ed. P.L. Bonner (Johannesburg, 1977).

12. The term is not meant to mean "near-Marxists", but in contradistinction to "palaeoMarxist" (never to my knowledge so used), for instance those members of the South African Communist Party of whom R.W. Johnson writes "had the South African revolution produced its own Lenin, he would undoubtedly have been drummed out of the CPSA", How Long Will South Africa Survive? (London, 1977), p. 25.

13. Stanley B. Greenberg, Race and State in Capitalist Development: Comparative Perspectives (New Haven and London, 1980).

14. Belinda Bozzoli, "Capital and State in South Africa", Review of African Political Economy 11 (1978):49; and R.K. Cope, Comrade Bill, the Life and Times of W.H. Andrews Miners' Leader (Cape Town, 1955), p. 140. 
society into the pre-industrial colonial economy and its labour process. Wallerstein's analysis of the growth of ethnic groups elsewhere in Africa would certainly suggest that such an approach might well be fruitful.

However, it is not such an easy task as it might appear at first. Since the theoretical implications of the subject for the understanding of modern South African society have not been fully grasped, the literature is at best spotty. For instance, there is as yet no study of the effects of the abolition of slavery on the economy of the Cape, nor any appreciation of the ways in which the ex-slaves were, or were not, maintained in a position of extreme subjugation. The importance of this would appear obvious, since it is not possible to explain the development of racial stratification in the Cape Colony (or anywhere eise for that matter) merely as a consequence of siavery. Not only would that entail that no explanation of how the patterns established under slavery could be transferred to the post-slavery era, but, more importantly, slavery as such cannot account for a system of social stratification in which there is a clear distinction between white and black. ${ }^{18}$ The legal dichotomy between slave and free was far more crucial than that between black and white, since there were many who were black but not slave. This changed with the abolition of slavery. There was no longer any legal mechanism to maintain the control of the owners of agricultural or other property over their labour force. The measures adopted then were likely to apply to all those who were dark of complexion since this became the main signal for subordination.

In this process, the Masters and Servants Ordinance of 1841 was of crucial importance at the Cape. ${ }^{19}$ It was passed just seven years after the abolition of slaavery and three after the ex-slaves had been released from the necessity of continuing working for their erstwhile masters. It can thus be seen as an attempt to regulate the labour situation which was beginning to get out of hand, especially as in the aftermath of emancipation large numbers of slaves left the farms on which they had worked and moved to the towns and villages of the Cape. The purpose of this ordinance was to delineate the conditions of contracts between employer and employee, as a means of enforcing the availability of those labourers that the farmer - it seems to have had less real effect in Cape Town itself - required and had been able to obtain. There seems to have been no possibility of a free market in labour in particular because the same ordinance explicitly forbade combinations. Therefore, especially since the contracts between master and servant could be made orally - and in a case of dispute the magistrate was far more likely to accept the word of the master than of the servant - and since the penalties for desertion were stringent, the effect of the ordinance, as its intention, was to

18. It may be different in those societies which did not make such a stark distinction, but: which included a specific mulatto stratum within their system of stratification, but wherever: there was slavery coupled. to racial distinction, there was also a large number of free blackssil coloureds. Certainiy there was at the Cape.

19. The best description of these measures and their effects is still J.S. Marais, The Cape Coloured People, 1652-1937 (Oxford, 1939), pp. 177-215. 
It may well be that the access to political power enjoyed by a large section of the working class (the white part) in the first quarter of this century was of major importance in the eventual transition from the relatively untrammelled hegemony of imperial (mining) capital before the 1920s to the far more diversified situation of later times, though this is not to overlook the important stimulus to South Africa manufacturing given, paradoxically, by the world economic depression of the 1930s. In other words, in the structuring of modern South Africa, the capitalists may have made their own history "but not of their own free will; not under circumstances they themselves have chosen, but under the given and inherited circumstances with which they are directly confronted". ${ }^{15}$ Those circumstances were a particular distribution of power within South Africa, which derived from the outcome of pre-industrial social developments and which could not be obliterated even by the Randlords, even by Milner. ${ }^{16}$

If this analysis is correct, then clearly it becomes necessary to place increasing emphasis on pre-industrial South Africa in an attempt to comprehend the causes of differential access to power among the various ethnic groups in statu nascendi in that society. This attempt must begin from the recognition that the Cape Colony, the Transvaai, the Orange Free State and Natal existed on the fringes the periphery to use the modern jargon - of the capitalist world system as it had developed in the aftermath of the Industrial Revolution. The ties were clearly more direct with the coastal colonies than with the interior. As has been shown, an older school of historians argued that it was among the Dutch-speaking whites of the interior, in particular, that the tendency towards racist ideas developed most strongly and that these ideas were carried over into the industrial period. The consequence of this, as has already been mentioned, was that racial stratification was seen in some way as an atavistic survival of a pre-capitalist, primitive way of life, which would wither away with the flowering of the modern system. The argument was that there was something about the condition of life on the frontier which tended towards a strengthening of group consciousness and thus of racial exclusiveness. However, the logical and evidential flaws in such an argument have been clearly demonstrated, notably by Martin Legassick. ${ }^{17}$ even if they have been replaced by too great an emphasis on the industrial period for the explanation of the development of racial estates (not, it must be admitted, the prime concern of Marxist historians). It is therefore worth investigating the hypothesis that the development of such estates within colonial society derived from the differential incorporation of the various groups of Southern African

15. The reference is of course to Karl Marx, "The Eighteenth Brumaire of Louis Napoleon", in Surveys from Exile (Harmondsworth, 1973; Penguin edition), p. 146. It is notable that in his "Mining Capital, the State and Unskilled White Workers in South Africa, 1901-1911" [Joumal of Southern African Studies 3 (1976)], Robert Davies makes a very similar point, but for him the determinant class struggies did not begin before 1892 .

16. Donald Denoon, A Grand Mlusion (London, 1973).

17. "The Frontier Tradition in South African Historiography", in Economy and Society in Pre-Colonial South Afrika, ed. Shula Marks and A. Atmore (London, 1980). 
maintain a very large proportion of the ex-slaves in very much the same effective position of subordination as that from which they had been officially emancipated.

The ordinance had a further important effect in that it, and a variety of other methods of labour control in the post-emancipation Cape, had the result of obliterating the distinction that had always been maintained between the slaves and the Khoisan. The latter, descendants of the indigenous inhabitants of the area, had been slowly dispossessed of their hunting and grazing grounds and stock over the course of the seventeenth and eighteenth centuries. This had resulted in a guerrilla war with the so-called "Bushmen" which lasted throughout the eighteenth century and indeed, in certain areas, well on into the nineteenth, ${ }^{20}$ and in the trekking of a large number of Khoi away from the southern Cape into the interior, where they founded new political units, often on a scale far larger than those with which they had previously operated. ${ }^{21}$ However, although both these phenomena can be clearly seen as a reaction to the loss of land, there are frequent indications that they should also be considered as a form of opposition to farm labour, and to the conditions under which they were forced to labour. For, even if many were able to escape being incorporated in the colonial economy as labourers, most were not. Even as early as the 1770s, the governor of the colony had written that there were no longer any Khoi who were not in the service of the farmers. ${ }^{22}$ By the beginning of the nineteenth century, the government had come to the conclusion that it was necessary to institute a system of registration and pass laws on the Khoisan, which had the effect, as they were no doubt meant to, of restricting the mobility of the Khoi to the extent that their bargaining power as against their employers was so reduced that they were placed in a position little different from that of the slaves. Indeed, since the employer had no feeling that he had invested his own capital in the labour power of the Khoi, the treatment of the Khoi was very probably worse that that of the slaves. To a certain extent that position was ameliorated when in 1828 the specific restrictions on the Khoi were removed, and they were placed on a precisely equal legal footing with the other free inhabitants of the colony. It was in this position that the great majority of them came to be placed in the disadvantageous status that the Masters and Servants Ordinance imposed on those who were the servants.

Thus, subsequent to the abolition of slavery, the subservience of labour to employers was ensured by legal measures. The Ordinance of 1841 did not fully satisfy the employers, however (but then, in any arrangement, the beneficiaries will believe that they can still gain more). There was thus considerable agitation to modify the measures, since the farmers, in particular in the more outlying

20. Shula Marks, "Khoisan Resistance to the Dutch in the Seventeenth and Eighteenth Centuries", Journal of A frican History 13 (1972).

21. The most notable of these were in Namibia. See H. Vedder, South West Africa in Early Times, trans. C.G. Hall (Oxford, 1938).

22. G.McC. Theal, ed., Belangrijke Historische Dokumenten, vol. 1(Cape Town, 1891), part 3, p. 11. 
districts, continued to suffer from a labour shortage and viewed this as a result of desertion and contract-breaking. Therefore, as soon as the Cape Colony received a parliament competent to amend the ordinances of the previous fifty years, a new act was passed, in 1856, which considerably tightened up the control that employers could exercise over their labour. This act, with relatively minor amendations, remained in force until $1974 .{ }^{23}$

At the same time, a variety of informal methods for the control of labour were being instituted. Most notorious and effective of these was the so-called tot-system, whereby, in effect, the farmers ensured that their labourers became so dependent on Cape wine that they could no more break the bonds with their master than a heroin addict can escape from his or her pusher. But there were also a number of share-cropping arrangements which kept the labourer tied closely to his land. Even in the aftermath of the emancipation of slaves and the abolition of Khoisan disabilities, the land-owners and their mercantile allies had been able to recreate a labour-repressive social system in the Cape colony, which lasted well into the twentieth century, if indeed it has yet ended, which is doubtful.

It was not only in those areas where the farmers had to restructure the system of labour control in the wake of the abolition of slavery and the dispossession of the Khoisan that systems of labour repression developed. That area, after all, was but a fraction of the land that was to become South Africa, and the people on whom those measures made themselves felt were of a very different cultural and historical background than the majority of the inhabitants of the country. Moreover, the political economy of the farms which had been occupied by Europeans since the late seventeenth century was of a different quality from that which was established during the nineteenth century when colonists came to conquer and subdue the eastern Cape Province, the Orange Free State, Natal and the Transvaal. In these areas, there was not such a great emphasis on putting men and women to work on the farms since only slowly did there develop a full system of capitalist agriculture based on production for a generally overseas market. When this did happen, the commodity produced was generally wool, and it was always possible to combine the large-scale sheep flocks of the master with African agriculture (which required relatively little land to feed a family) without their getting in each other's way. The same was true as regards the cattle herds of the interior although in both cases there was competition between African-held stock and that of the intruding colonists, a conflict which was resolved by the dispossession of the Africans. This was coupled with the development of methods of extracting surplus from the Africans, for the benefit of those within the white community who had access to the economy of the coast, which could be used to provide those goods that could ensure real power in the interior. The importance of the arms trade ${ }^{24}$ and of its limitation to the colonial population (or indeed to

23. Colin Bundy, "The Abolishion [sicl of the Masters and Servants Act", South Africa Labour Bulletin 2 (1975).

24. Anthony Atmore, J.M. Chirenje and S.I. Mudenge, "Firearms in Central Africa", Journat of African History 12 (1971). 
a certain section of even that population, since half-castes were excluded) can be seen in this light.

This process of surplus extraction can be seen most clearly in the Transvaal. ${ }^{25}$ 
land, came into being, in competition with the white farmers who were the employers of African labour. ${ }^{27}$ Indeed the presence of this African class, and its allies among the merchants of such towns as Kingwilliamstown, gave the political life of the region its particular tint. Cape liberalism, a movement which stressed economic freedoms as opposed to the coercive labour patterns of the rest of the Cape, found its base very largely in the east. The exceptionality, however, and eventual impotence of Cape liberalism put into focus the content of the dominant class relations with the rest of pre-industrial South Africa. ${ }^{28}$

It would be easy, but laziness of thought, to slip from the determination of class stratification within pre-industrial South Africa, based on the regularity of patterns of exploitation, to the equation of these classes with estates. There might be an excuse for it, if it could be shown that a similar laziness pervaded the minds of those nineteenth-century South Africans who established the systems. After all, all members of the dominant classes were "white" because the system of class relations was established as a result of the European colonisation of South Africa. Nevertheless, such an approach has logical problems. In the first place, by no means all whites belonged to the dominant classes. Increasingly during the nineteenth century there were those who had the status of white - as burghers of the Transvaal Republic in particular - but who did not own land and were dependent on other whites for their livelihood, and indeed for their status. These were generaily known as bywoners. However, the richer whites - those whom Trapido calls the "notables" - could not realise the surplus from the Africans without the help of their clients, as supervisors, as adjuncts by tax-collections, where necessary as an armed force. Thus although there was a steady increase in the level of economic differentiation within the white community and although this played its part within the complicated political strife of the Republic, nevertheless, the mutual interdependence of landholder and bywoner and their mutual interest in exploiting the Africans meant that political contests remained within certain bounds. The Africans were never called in to redress the balance of the whites.

Similar alliances were to be found elsewhere in southern Africa outside the Transvaal. Indeed, very often it was the merchants in the country towns above the Cape and the Orange Free State who represented the interests of the farmers on whom they were dependent for their custom. ${ }^{29}$ The only areas where a different political expression might be found to that whereby the interests of that alliance were translated into terms of racial exclusiveness were, as we have seen, the eastern Cape and also Cape Town, where the presence of the port and the growth of a

27. Colin Bundy, "The Emergence and Decline of a South African Peasantry", African Affairs 71 (1972).

28. Stanley Trapido, "Liberalism in the Cape in the 19th and 20th Centuries", SSA 4 (1974).

29. For an example, see K.W. Smith, From Frontier to Midlands, a History of Graaff-Rein District (Grahamstown, 1976). 
so-called "coloured" artisanate (already present in the days of slavery) gave a a flavour to social relations not found elsewhere.

A second logical problem is the converse of the first: by no means were all ex-slaves, Khoisan, Africans and their descendants, at all times in a position of dependence. There were many - the Griquas are the best known, but by no means the only example ${ }^{30}$ who were able to accrue not insubstantial wealth within the colonial economy. However, over the course of the nineteenth century these individuals either lost their prominence or "became" "white". To a certain extent, this repression could be attributed to a desire on the part of the ruling groups within South African society to maintain and extent a form of stratification based on ethnic ascription - in other words, to white racism. However, that racism itself derived from a very definite economic motivation, from the systems of exploitation that had been developed. In the mid-nineteenth century, the ruling class of South Africa maintained its power by appropriating surplus from men and women who, almost without exception, were black, whether they were of slave descent or from among the various African peoples who, if they had not already been conquered, or at least subjugated, were in the process of undergoing that fate. For the ruling class, the major problem was to maintain that subordination. Clearly this required that social mobility on the part of the lower orders, who were all black, should be kept to a minimum. Since, at least in the Cape, there were no longer any legal provisions, such as slavery, for effectively denying social mobility to the mass of the population, this could only be effected by the informal prevention of access to the instruments of advancements, land, credit ${ }^{31}$ and so forth. And those who had chanced to acquire those instruments were slowly deprived to them. To ensure that those who laboured or paid rent continued to do so, even those who did not do so, but who who could be identified with those who did, were put in a position where they had no option besides that of labourer or tenant or both.

With the development of the diamond-and gold-mines in the last quarter of the nineteenth century, the character of social relations in South Africa changed enormously, and not only in the towns and mining settlements. The massive new opportunities for marketing produce completely altered the fabric of rural life ${ }^{32}$ On the one hand, the possibilities of profit enduced the owners increasingly to turn to more direct personal production, and, so far as possible, to dispense with tenantries, not only black - this was the whole purpose of the 1913 Lands Act - but also white. On the other hand, with the introduction of a far more efficient system of policing - the police could now be paid - there disappeared the necessity for the land-owners to maintain numbers of clients to ensure their

30. See Robert Ross, Adam Kok's Griquas: A Study in the Development of Stratification in South Africa (Cambridge, 1976).

31. Tony Kirk, "Progress and Decline in the Kat River Settlement, 1829-1854", Journal of African History 14 (1973):415.

32. Tim Keegan, "Peasants, Capitalists and Farm Labour: Class Formation in the Orange River Colony, 1902-1910", SSA 9 (1979); and Paul Rich, "The Agrarian Counter-revolution in the Transvaal and the Origins of Segregation", in P.L. Bonner, Working Papers. 
continued control over their land. Therefore, slowly, the bywoner disappeared from the land and came to swell the body of white industrial workers, above all in the towns along the Witwatersrand. Frequently, they had to camp with very considerable poverty. ${ }^{33}$ They were to form the backbone of the various Afrikaner populist parties which have been of such importance in the politics of white South Africa, although the more nationalist elements in those parties only developed well into the $1930 \mathrm{~s}$, when the poverty of the white workers was decreasing and the original opposition to the interests of capital had been transferred into an uneasy alliance with them. In part, that alliance developed out of the changing nature of the South African economy, which came to need an increasing proportion of skilled technical and supervisory personnel, but it also derived from the fact that, over the first quarter of this century, the white workers had fought and won a bloody class struggle against, in particular, the mine-owners. ${ }^{34}$ In contrast, the blacks alongside whom they worked had lost a similar struggle and have as yet been unable to break out of the position of inferiority that that defeat condemned them to. It would be possible to explain this differential accomplishment in terms of contingencies, such as the fact that the whites, with the heavy levening of workers from Europe, were more skilled in the techniques of trade-union organisation, or the fact that the blacks more frequently maintained their links with the countryside, or were forced to do so by the institution of migrant labour and the payment of such low wages that the subsistence of the family depended very largely on the agricultural production of the wives, children and old men left behind - and therefore they did not have a stake of quite the same import in the struggle as did the whites. But such explanations, though no doubt of marginal importance, miss the kernel of the matter. They do not investigate the relative strength and weakness of the various parties. The whites were so much more powerful than the Africans in the new industrial struggle because they had particular rights within the society which the Africans and others did not have. These related to their full participation in the political process. And these they had retained from pre-industrial times, when the class struggle consequent upon the establishment of colonial hegemony allotted to those not of colonial descent very different positions within the colonial economy than to those with that legitimation. From there began the estates, racially split and often racistically justified, of modern South Africa.

33. John Mawbey, "Afrikaner Women of the Garment Union during the Thirties and Forties", in Essays in Southern African Labour History, ed. Eddie Webster (Johannesburg, 1978).

34. Robert Davies, "The 1922 Strike on the Rand: White Labour and the Political Economy of South Africa", in African Labor History, ed. P.C.W. Gutkind, Robin Cohen and Jean Copans (Beverly Hills and London, 1978). 